\title{
Access to information in Belgium
}

This paper provides a general overview and the context of the regulation of transparency in Belgium. During the EGPA Conference we go one step further. We will focus on one specific issue: the impact of new communication tools (Facebook, Twitter) on Transparancy and the question if current regulation (as it is in Belgium) is sufficient.

Stef Keunen ${ }^{1}$ and dr. Steven Van Garsse ${ }^{2} 3$

\section{Introduction}

Prior to the Second World War, the freedom of expression ${ }^{4}$ and the freedom of the press ${ }^{5}$ were mainly seen from the point of an active right of the press to provide information without interference from the government. Since then there has been an evolution where the freedom of information is also seen from the point of view of the receiver as a passive right to be informed. At the same time, there has been an evolution resulting in an active obligation for the government to create a policy and an infrastructure that allows the freedom of expression to become a fundamental social right. ${ }^{6}$

Following the Global Right to Information Rating is Belgium not exactly an exemplary student regarding the right of access to information. In the last year, Belgium was awarded 59 out of 150 points regarding the following seven criteria: right of access (2 out of 6), scope (17 out of 30), application procedures (14 out of 30), exceptions (15 out of 30), appeals (11 out of 30), sanctions ( 0 out of 8 ) and promotional measures ( 0 out of 16$)$. Belgium is with this score ranked at place 101 out of the 111 states which were investigated. ${ }^{7}$ This chapter summarises the national and regional legislation for access to documents and information in Belgium and discusses some of the implications in practice. It also points to some challenges that lie ahead.

In Belgium the nineties were of major importance for the development of the right of access to information. Transparency was more and more considered to be a prerequisite of good governance. Transparency and access to information is furthermore indispensable for increasing citizens' understanding of government decision-making and for enhancing public's confidence in the administration and fostering open decision-making. In 1991, the first legislation concerning access to information within Belgium was introduced by the federate parliament of Flanders. ${ }^{8}$ Subsequently, a Federal charter on good governance followed ${ }^{9}$. Until 1993 there was no constitutional right on access to administrative documents. In that year, the Belgian

Hasselt University, Centre for Government and Law.

University of Antwerp \& Hasselt University, Centre for Government and Law. Head of the research Unit Administrative law and Public Administration.

Special thanks to Karen Deckers who helped preparing an earlier version of this text.

Art. 19 Coordinated version of the Belgian Constitution of 17 February 1994, Belgian Official Gazette (hereafter referred to as BS) 17 February 1994.

5 Art. 25 Belgian Constitution.

6 Explanatory note accompanying the legislative proposal of the government to implement an article 24ter in the Constitution concerning access to information, Parl. St. Kamer 1992-93, no. 839/1, 1-2.

The Global Right to Information Rating (2017) http://www.rti-rating.org/country rating.php.

The Global Right to Information Rating is a programme which comparatively assesses the strength of legal frameworks for the right to information from around the world. At the heart of the methodology for applying the RTI Rating are 61 Indicators. For each Indicator, countries earn points within a set range of scores (in most cases 0-2), depending on how well the legal framework delivers the Indicator, for a possible total of 150 points. The indicators are divided into seven different categories, namely: Right of Access, Scope, Requesting Procedures, Exceptions and Refusals, Appeals, Sanctions and Protections, and Promotional Measures (http://www.rti-rating.org/methodology/).

8 Flemish Decree of 23 October 1991 concerning access to administrative documents within the institutions of the Flemish government, BS 27 November 1991. Currently the matter is regulated in the Flemish Decree of 26 March 2004.

9 Handvest 4 december 1992 van de gebruiker van de openbare diensten, BS 22 January 1993 
Constitutional legislator implemented an article concerning access to information. ${ }^{10}$ Article 32 of the Belgian Constitution states: "Everyone has the right to consult any administrative document and to obtain a copy, except in the cases and conditions stipulated by the laws, federate laws or rules referred to in Article 134." It is important to stress that this article not only enshrines the principle of freedom of access to information, but also contains a rule of division of power between the federal state and the federated entities. ${ }^{11}$ As a result of the federal structure and this particular provision, the different legislatures adopted their own legislation concerning the right on access to information. ${ }^{12}$ Prior to this legislation, a bureaucratic attitude focused on secrecy was the rule within the administration. Documents were often rejected arbitrarily. ${ }^{13}$ Nowadays the right on access to administrative documents cannot be seen as merely a general principle of public administration. It must, following jurisprudence of the Constitutional Court and the Council of State, be regarded as a genuine fundamental and constitutional right. ${ }^{14}$

The law in practice is not unimportant. It has as one of the beneficial effects that the persons who consider to bring legal proceedings, can examine their file prior starting some proceeding. They will take informed an action, which result could not be achieved if the citizens only got to view their file in the registry once the procedure is started. ${ }^{15}$

Hereafter, we will discuss the federal legislation ${ }^{16}$ and the legislation of the Flemish Region as an example of how the federated entities legislated ${ }^{17}$. The acts only contains the minimum guarantees for access to administrative documents. When special laws require a greater access, these laws should be applied.

\section{Beneficiaries of access to information in Belgium}

The Federal Act of 11 April 1994 states that passive transparency implies that everyone has a right of access to administrative documents, under the conditions set out by the law. ${ }^{18}$ The notion 'everyone' leaded to a debate whether or not this notion comprises legal entities. Later on it became clear that the term 'everyone' comprises natural persons, non-profit associations, organisations, unincorporated associations as well as (private or public) corporations. ${ }^{19}$ The Belgian Council of State stipulated the following:

\footnotetext{
“The terms 'person' and 'every' in the Constitution and the Federal Act concerning access to information indicates that the right of access to administrative documents applies to all, both the natural and legal persons. Nothing in this law refutes this interpretation [...] There is no reason to limit the scope of the Federal Act concerning access to information only to natural persons". ${ }^{20}$
}

10 Constitutional reform of 8 June 1993, BS 29 July 1993, 15.584 (Article 24ter), consolidated version in BS of 17 February 1994 (in the consolidated version, Article 24ter turned Article 32).

11 See also BAMPS (1996), pp. 23; SCHRAM (2008), pp. 40; ORNELIS (1998) pp. 13; BREMS (1995), pp. 620.

12 LEWALLE, DONNAY and ROUSOUX (2008), pp. 57.

13 SCHRAM, (2010p, pp. 10-11; VANDE LANOTTE and GOEDERTIER (2010), pp. 657.

14 Constitutional Court 25 March 1998, no. 17/97; Constitutional Court 15 September 2004, no. 150/2004; Council of State 2 October 1997, no. 68.610, Delwart; Council of State 12 December 2003, no. 126.340, Vanderzande \& Hallumiez; Council of State 3 October 2011, no. 215.506, Baumwald.

15 Council of State, 7 November 2003, nr. 125226, Goormachtigh a.o.

16 Wet 11 april 1994 betreffende de openbaarheid van bestuur, BS 30 juni 1994 (ed. 2). Hereafter referred to as: Federal Act of 11 April 1994 concerning access to administrative documents/Federal Act of 11 April 1994)

17 Vlaams Decreet 26 maart 2004 betreffende de openbaarheid van bestuur, BS 26 maart 2004, 53371. Hereafter referred to as: Flemish Decree of 26 March 2004 concerning access to administrative documents/Flemish Decree of 26 March 2004.

18 Article 4 Federal Act of 11 April 1994.

19 Judgements of the Council of State: Council of State 14 October 1996, no. 62.547, nv Electrification du Rail (the use of the extensive terms 'everyone' and 'each' in the Constitution and in the Federal Act of 11 April 1994 indicates that the right of access to information applies to all, this means natural persons and legal corporations); Council of State 21 October 2013, no. 225.162; Council of State 12 May 2015, no. 231.194, gemeente Schaarbeek (neither the constitution, nor the federal act explicitly exclude public corporations; therefore there is no justification that only public corporations cannot benefit from the right of access to information. Public corporations however can only rely on the right of access to information in relation to their competences).

20 Council of State 14 October 1996, no. 62.547, NV Electrification du rail. 
A similar provision is included in the Flemish Decree concerning access to administrative documents. ${ }^{21}$ This Decree clearly states that all natural persons, legal persons or groups thereof have a right of access to administrative documents.

The content of the right of access to information is the same in the Decree as in the Federal Act. The right of access to administrative documents consists of the right for everyone to consult a document onsite, to receive explanations about the document and to receive a copy. ${ }^{22}$ The possibility to receive explanations about a document was considered to be necessary in the light of a meaningful right of access to information. The specific language used in administrative documents or the technicality of documents would make a mere consultation ineffective. ${ }^{23}$

The obligation on the other hand does not imply to give "a clear overview of all the documents contained in the file", or to make an inventory of a "file". ${ }^{24}$ The Council of State ruled in a similar sense that the right to access does not extend beyond providing information that is recorded on a carrier. So far as the difference in points at the applicant's concerns, is not explained in a document, the applicant asks for non-existent data (see below). ${ }^{25}$

The administrative authority can submit the right to receive a copy to the payment of a fee. At the federal level the amount of the fee is determined by a Royal Decree ${ }^{26}$ The Flemish Decree also provides the possibility to ask a charge based on a reasonable cost for a requested copy. In practice however most entities do not charge a fee. What the Flemish government departments concerns, can this be partly explained by the fact that no retribution can be asked because of the fact that Flemish government (still) has not taken any executive order on retribution for copies.

Article 5 of the Federal Act and article 17 of the Flemish Decree requires that the administrative authorities register the applications to get access to administrative documents. Such a register undoubtedly provides the ability to deliver statistics concerning the requests. However, on the federal level there is no general register of all requests; while in Flanders such a general registration exists. In the different year reports of the Flemish Appellate Body on the Openness of Government the number of applications is registered. The following scheme gives an overview of the years 2012-2013 until 2015-2016.27

Article 7 Flemish Decree of 26 March 2004.

Article 4 Federal Act of 11 April 1994; article 7 Flemish Decree of 26 March 2004

Explanatory note accompanying the Federal Act of 11 April 1994 concerning access to administrative documents, Parl. St. Kamer 1992-93, no. 1112/1, 14 (hereafter referred to as: Explanatory Note Federal Act of 11 April 1994); Explanatory note accompanying the Flemish Decree of 26 March 2004 concerning access to administrative documents, Parl. St. Vl. Parl. 2002-03, no. 1732/1, 21 (hereafter referred to as: Explanatory Note Flemish Decree of 26 March 2004)

24 Council of State, 24 June 2014, no. 227.809, Verrycken.

25 Council of State 31 January 2012, no. 217.626, XXX.

26 Article 12 Federal Act of 11 April 1994; Royal Decree 17 August 2007 to determine the amount of the fee due for receiving a copy of an administrative document or an environmental document, BS 14 September 2007.

The Court of Justice judged that the term 'reasonable amount' must be interpreted as follows: "Consequently, any interpretation of what constitutes 'a reasonable cost' for the purposes of Article 5 of the directive which may have the result that persons are dissuaded from seeking to obtain information or which may restrict their right of access to information must be rejected. the term 'reasonable' for the purposes of Article 5 of the directive must be understood as meaning that it does not authorise Member States to pass on to those seeking information the entire amount of the costs, in particular indirect ones, actually incurred for the State budget in conducting an information search." (European Court of Justice 9 September 1999, C-217/97, ECLI:EU:C:1999:395, Commission v. Germany, para. 47-48).

27 The counting of applications starts on the first of July and ends on the last day of the month June.

The numbers includes the applications made to the following administrative authorities: a selection of 15 Flemish municipalities (three municipalities per province); the 5 Flemish provinces; the departments of the 12 policy areas of the Flemish administration (Public Governance and the Chancellery; Finance and Budget; Flemish Foreign Affairs; Economy, Science and Innovation; Education and Training; Welfare, Public Health and Family; Culture, Youth, Sport and Media; Work and Social Economy; Agriculture and Fisheries; Environment, Natura and Energy; Mobility and Public Works; Spatial Planning, Housing Policy and Immovable Heritage); the Flemish Parliament; the Flemish Ombudsman; the Flemish Peace Institute; Flemish Office of the Children's Rights Commissioner and the cabinets.

The data are based on the different year reports of the Flemish Appellate Body on the Openness of Government (online available at: http://openbaarheid.vlaanderen.be/nlapps/docs/default.asp?id=28\&order=). 
Figure 2.1. Number of applications to get access to documents in Flanders

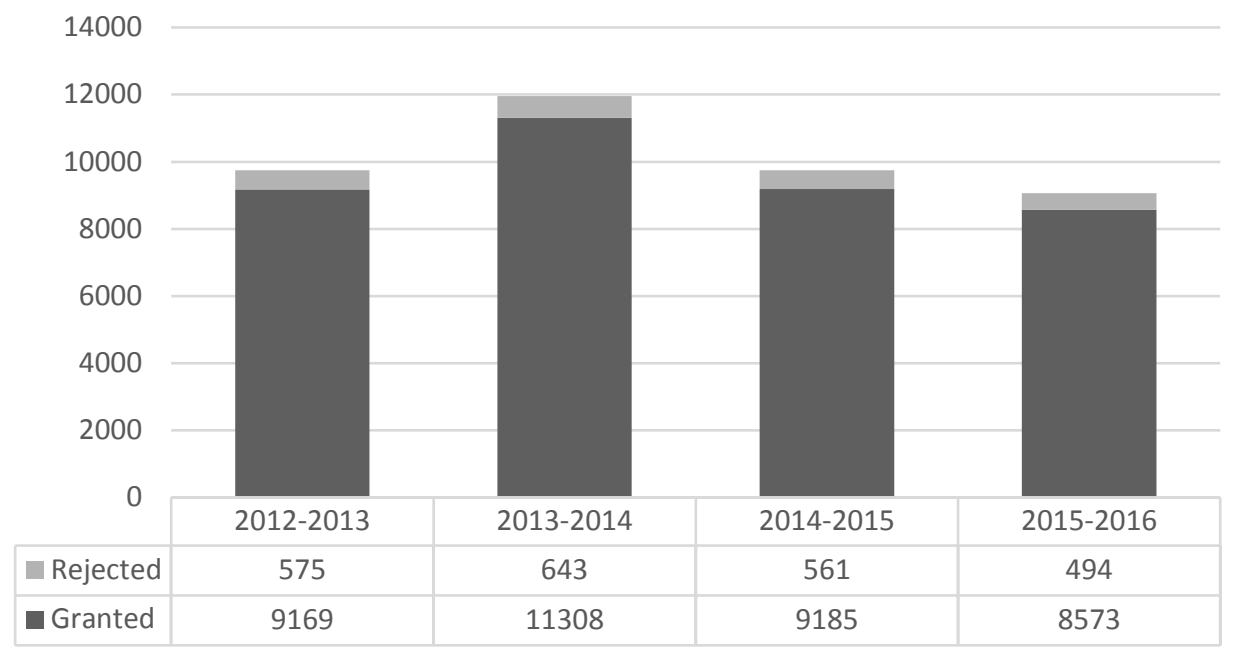

By analysing the concrete applications with the different institutions, a tendency can be observed. An application will be made faster if the administrative body, possessing the information, is located closer to the citizen (e.g. municipalities, provinces). This can be explained by the fact that a citizen is more aware of the relevant decisions of authorities closer to him or her. The following figure describes the amount of applications within the different spheres of government. This figure clearly shows that only 14 cities (of the 308 municipalities in Flanders) almost reaches the number of request done with the Flemish government authorities.

Figure 2.2. Number of applications in the different levels of government within Flanders (2015-2016)

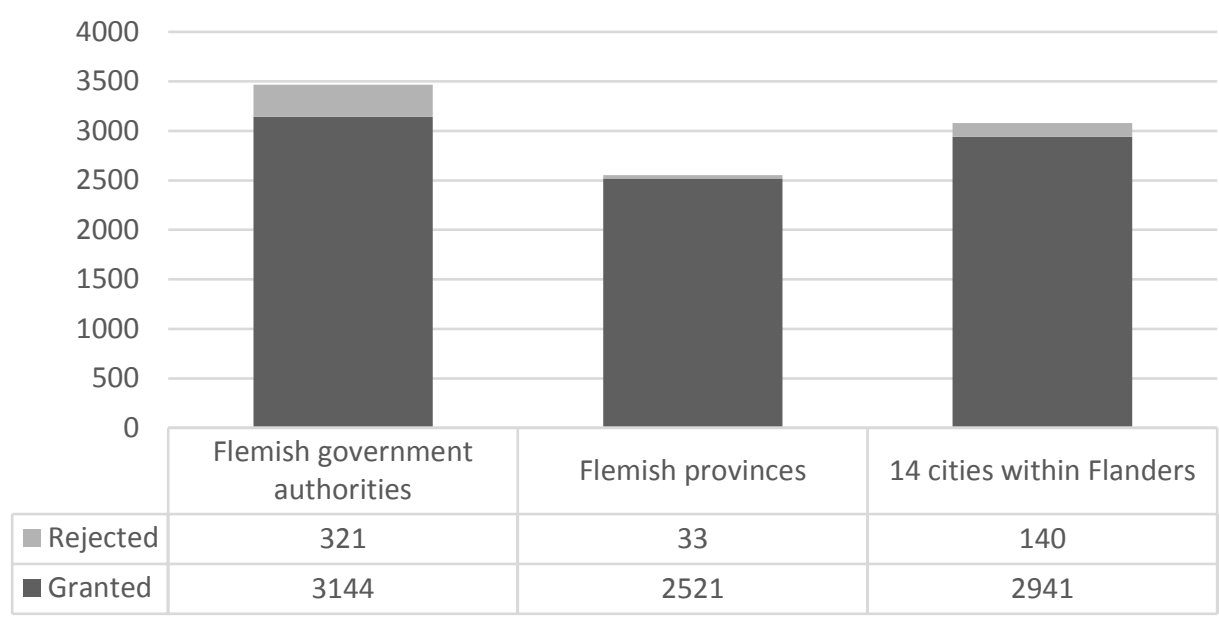

Unfortunately, the year reports do not gather information about who made the request: individual citizens, NGO's, non-profit organisations,...

A last remarkable fact, after analysing the year reports is the relatively low number of rejections. From all the applications from July 2015 until the end of June 2016 only $5.3 \%$ were rejected. However, we have to be critical regarding this percentage because the Year Report doesn't contains all applications for access to administrative documents in Flanders (see note no. 27). From a broader survey in $2011^{28}$ the following figures can be derived:

28 http://openbaarheid.vlaanderen.be/nlapps/data/docattachments/EvaluatieOpenbaarheidBestuur_LR.pdf accessed on 1 march 2017. 


\section{Figure 2.3. Applications granted, granted in part or refused (2011)}

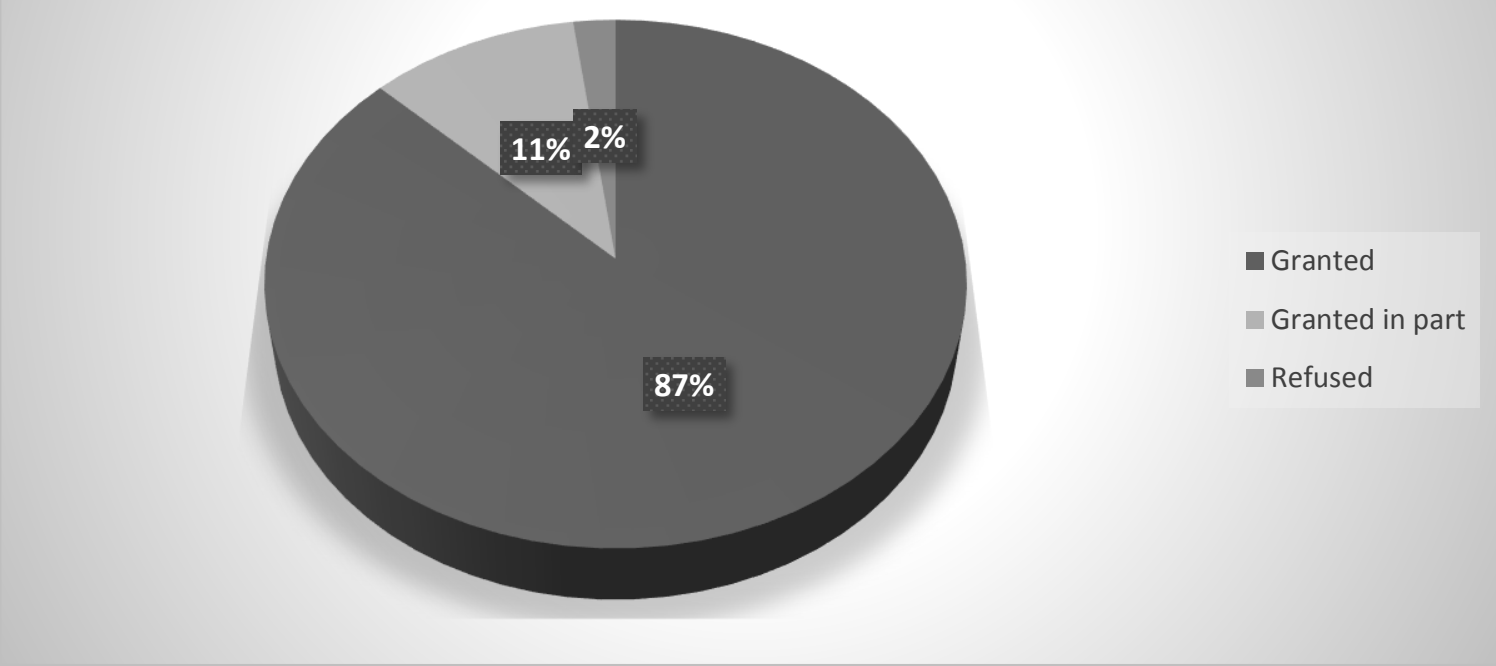

That study also emerged that the public requests were submitted as follows: an average percentage by letter (46\%); by e-mail (35\%); through personal delivery $(12 \%)$ and by fax $(2 \%)$. Thereby highlighted a clear trend towards more requests by email. Matters which concern the requests happen: urban zoning and planning (over 50\%); Public Procurement (tenders and selection of tenders) (22\%); Environmental records (13\%).

\section{Scope of the legislation on transparency}

3.1. Scope ratione personae: entities which are bound by the law

As a matter of course, the Federal Act and the Flemish Decree on access to administrative documents have a different scope ratione personae. However, this doesn't imply that they have no relevance to one another in terms of the scope ratione personae. In order to determine the scope of the Federal Act, a distinction must be made between the procedure and the grounds for exceptions on the right of access to administrative documents. The Federal Act has to be applied in its entirety by all federal administrative authorities. ${ }^{29}$ Additionally, all other administrative authorities (e.g. Flemish authorities, municipalities, provinces etc.) have to apply the Federal Act regards to the limitations on the right of access to administrative documents concerning federal competences. ${ }^{30}$ In other words, the non-federal administrative authorities are only bound by the limitations set out in the Federal Act. A similar provision exists in the Flemish Decree. ${ }^{31}$

In the federal Act the term 'administrative authority' is used to determine the scope. The federal legislator defined the term 'administrative authority' as followed: ${ }^{32}$ "An administrative authority as referred to in article 14 of the Coordinated Laws on the Council of State". Article 14 of the Coordinated Laws on the Council of State does not give a concrete definition either, but there is comprehensive case law from the Council of State, the Constitutional Court and the Supreme Court (Hof van Cassatie) about the interpretation of the notion 'administrative authority' in this article. In this regard, the Supreme Court states: "That institutions established or recognised by the federal government, the government of the communities and the regions, the

Article 1, par. 1, a) Federal Act of 11 April 1994

Article 1, par. 1, b) Federal Act of 11 April 1994.

See art. 4, §2 Flemish Decree of 26 March 2004.

Article 1, par. 2, $1^{\circ}$ Federal Act of 11 April 1994. 
provinces or the municipalities, who are entrusted with a public service and do not belong to the judiciary or the legislative power, are in principal administrative authorities, in so far as their functioning is determined and controlled by the government and in so far as they can take decisions which bind third parties". ${ }^{33}$ This last element of taking decisions which bind third parties is a decisive criterion, especially for private persons exercising public powers. Some institutions could be considered as administrative authority in certain circumstances, but are not in others. ${ }^{34}$

Furthermore, as a consequence of the case law of the Constitutional Court, article 14 of the Coordinated Laws on the Council of State was revised and now also includes the legislative assemblies or their bodies: the Court of Account, the Constitutional Court, the Council of State, administrative courts, bodies of the judiciary and of the High Court of Justice, when they take decisions regarding public procurement and members of their staff. ${ }^{35}$ The Attorney-General, the public prosecutor or the investigating judge cannot be considered administrative authorities if they compose and manage a criminal file. In other words, no information from a judicial file which is still being examined can be obtained under the Federal Act on the right of access to administrative documents. ${ }^{36}$

Where the notion of 'administrative authority' was already well-established in Belgian legislation and jurisprudence, this was not the case for the notion of 'federal administrative authority'. In a preliminary advice the Council of State gave a description of the latter notion. ${ }^{37}$ In general the notion includes federal administrations, public institutions and similar public services dependent of federal administrative authorities as well as private persons who are assigned with the execution of a federal public service. ${ }^{38}$ More specifically, the following persons or institutions are considered as federal administrative authorities: administrative institutions of the federal state, such as the King (in the circumstances where a minister is accountable) and the federal ministers, as well as civil servants when they are entrusted to make decisions by delegation. Members of the cabinet are not considered as administrative authorities because they are the personal staff of the minister and they cannot make decisions for which the minister is competent. Non-federal authorities on the other hand are the authorities dependent on other government levels, namely the communities and the regions, the provinces and the municipalities. ${ }^{39}$ Currently, a proposal is pending to amend the Federal Act by replacing the concept 'administrative authority' by the concept 'public authority' ${ }^{40}$

The personal scope of the Flemish Decree is defined in a similar way as the Federal Act. However, it was a conscious choice by the Flemish legislator not to use the term 'administrative authority', but the term 'public authority'. ${ }^{41}$ In general terms, the Flemish Decree applies to all instances within the Flemish community and the Flemish Region. ${ }^{42}$ Compared to the Federal Act, the Flemish Decree provides for a specific list to whom the decree applies. ${ }^{43}$ Additionally, the decree applies to other instances in so far as the decree limits or prohibits the access to administrative documents on grounds that fall within the scope of their competences. ${ }^{44}$ This last provision is similar to the above described provision of the Federal Act.

33 Cass. 14 February 1997, RW 1996-97, 1438.

34 For example: on the one hand the University of Leuven is not acting as an administrative authority by granting the construction of a university building to company $\mathrm{X}$, on the other side the University of Leuven is acting as an administrative authority when taking examination decisions (Council of State 31 July 2009, no. 195.486, nv Aannemingsmaatschappij CFE; Council of State 16 October 1981, no. 21.467, VAN NOTEN (1981-1982), pp. 491-493; see also VERSTEGEN (2002), pp. 801-814.

35 Art 14 of the Coordinated Laws on the Council of State as reformed by article 2 of the Federal Act of 25 May 1999. See the case law of the Constitutional Court: Constitutional Court 15 May 1996, no. 31/96 and Constitutional Court 29 January 2004, no. 2004/17 (online available at: http://www.const-court.be/). In the latter case, the Court ruled that by referring to 'administrative authorities as referred to in article 14 of the Coordinated Laws on the Council of State' the legislator wanted to adept to scope of the law to the evolution in the case law.

36 Council of State 8 February 2000, no. 85.177, Ghysels.

37 Cf. also Explanatory memorandum preceding the Federal Act of 11 April 1994 concerning access to administrative documents, Parl. St. Kamer 1992-93, no. 1112/1, 9-10.

38 See for an interesting example: federal Commission on Access to and Reuse of Administrative Documents 7 June 2016, no. 2016-50: the legislation is applicable to a government commissioner; See for another interesting example: federal Commission on Access to and Reuse of Administrative Documents 29 February 2016, no. 2016-25: the legislation is applicable to the Ombudsstelle für Energie/Ombudsdienst voor energie.

39 Explanatory memorandum preceding the Federal Act of 11 April 1994 concerning access to administrative documents, Parl. St. Kamer 1992-93, no. $1112 / 1,9-10$.

40 Legislative proposal to amend the Act of 11 April 1994 concerning access to administrative document, Parl. St. Kamer 2014, no. 0061/001, 4-5.

41 Explanatory Note Flemish Decree of 26 March 2004, 10; Council of State 6 December 2012, no. 221.641, Arteveldhogeschool.

42 The decree provides an enumeration of instances that fall within the scope of the decree, such as the Flemish parliament and the instances linked to it, the municipalities, the provinces, the public instances for public welfare and others. The enumeration ends with the 'all other instances within the Flemish community and the Flemish region' which indicates clearly that the enumeration is by no meaning exhaustive (art. 4 , $\$ 1$ Flemish Decree of 26 March 2004).

43 Art. 4, §1 Flemish Decree of 26 March 2004.

44 Art. 4, \$2 Flemish Decree of 26 March 2004. 
An 'instance' can be either an executive instance or an environmental one. ${ }^{45}$ In contrast to the Federal Act who gives no concrete definition of 'administrative authority', the Flemish Decree provides such a definition for the notion 'executive instance': ${ }^{46}$

“a) a legal person who is founded by or by virtue of the Constitution, a law, a decree or an ordonnance;

b) a natural person, a group of natural persons, a legal person or a group of legal persons who are determined and controlled in their functioning by an instance in the meaning of a);

c) a natural person, a group of natural persons, a legal person or a group of legal persons, in so far they are entrusted with the execution of a task of public interest by an instance in the meaning of a) or in so far they look after a task of public interest and take decisions that are binding on third parties."

The judiciary does not fall under the scope of this definition, except when they act in a capacity other than the judiciary. Parliamentary assemblies and the institutions linked to it are excluded of this definition, except in matters regarding public procurement and matters regarding the staff of their services. The executive is excluded of this definition in so far it acts as in a judiciary capacity. ${ }^{47}$

The interpretation ratione personae of the Flemish Decree generated some interesting case law, e.g. on the field of education institutions. ${ }^{48}$ There was a certain evolution about the interpretation of the scope related to education institutions. At first the Flemish Appellate Body on the Openness of Government considered that the free education institutions in accordance with article $3,1^{\circ}$, first paragraph, c) of the Flemish Decree only fell under the scope as far as they conducted a general interest tasks and took decisions that binds third parties. The Flemish Appellate Body on the Openness of Government ruled that the free education institutions in their relations with their staff had no unilateral and binding decision and that they are in that capacity not to be considered as governing bodies within the meaning of the Flemish Decree. Later, the Flemish Appellate Body on the Openness of Government ruled in compliance with Belgian legal doctrine that free education institutions fell indeed under Article $3,1^{\circ}$, first paragraph b), from the Flemish Decree. The operation of the educational institutions was at the discretion of the authority sufficiently determined and was under the control of the Flemish government. However, this interpretation proved too broad.

It was in fact later on decided by the Belgian Council of State that accredited private schools are to be considered as "executive instances" under "c" above. This means in practice that they are qualified as an executive instance in relation to the award of a degree as this is qualified as a decision that binds third parties, but not in matters relating to their staffing or in matters related to public procurement. As to public schools, the situation is quite different as they qualify as executive instances under ' $a$ ' or 'c'. Legislation on access to administrative documents is therefore relevant in all matters and for all documents.

Yet this is not to say that the scope of the Flemish Decree would be interpreted restrictively. On the contrary. With regard to external autonomous public institutions and government (owned) companies who serve public services, is (still) quite generally accepted that they are covered under the scope of the decree.

\subsection{Scope ratione materiae}

45 Art. $3,3^{\circ}$ Flemish Decree of 26 March 2004

46 The Flemish Decree also provides a definition for the notion of 'environmental instance' (art. 3, $2^{\circ}$ Flemish Decree of 26 March 2004 ) which is broader than the notion of 'executive instance'. The specific legislation for access to environmental information, the notion 'environmental instance' will be discussed further.

47 Art. 3, $1^{\circ}$ Flemish Decree of 26 March 2004.

48 See e.g. Council of State 27 March 2012, no. 218.680, Veys. 
The material scope of the Federal Act is defined by the notion 'administrative document'. The Federal Act gives an extensive interpretation to the notion 'administrative document'. It is defined as "all information, in whatsoever form, which is in the possession of an administrative authority". ${ }^{49}$ According to preliminary discussions in the parliament, the following forms of documents are included in the notion of 'administrative document': written documents, sound and visual recordings, magnetic tapes, floppy disks and other carriers of manually or automatically processes data. ${ }^{50}$ By way of illustration, the preliminary discussions state that reports, studies, even of non-official advisory commissions, some minutes and official records, statistics, administrative guidelines, circulars, contracts and permits, registers of public inquiries, reports of examinations, motion pictures, photographs and so on, are considered as administrative documents. ${ }^{51}$

The Flemish decree uses the notion 'executive document' to define the material scope of the right of access to information. An executive document is defined as: "the carrier, in whatsoever form, of data in the possession of an (executive) authority". 52 The term 'administrative document' has a very broad interpretation. ${ }^{53}$ This term also includes electronic information. In principle all information which can be found, even an e-mail or in the attachments within that e-mail, are subject to the principle of transparency. Although the notion is different than the one used in the Federal Act (administrative document), both legislations nonetheless have the same material scope..$^{54}$

An executive document in the possession of a staff member of an instance is considered to be a document in the possession of the instance in so far as it relates to the functions of the instance. ${ }^{55}$ By explicitly stating that a document in the possession of a staff member is deemed to be in the possession of the instance, the Flemish legislator wanted to prevent that documents were excluded from disclosure merely on the ground that certain data are the private property of a staff member or are located at his home. Thus it is important also for reasons of protection of privacy to make a clear distinction between documents that relate to the execution of the functions of the instance and documents regarding the private relation of the staff member with the government and other persons. Naturally only the former are subject to the right of access to information. ${ }^{56}$

\section{The procedure for access to administrative documents}

\subsection{The application procedure}

The procedure for requesting access to administrative documents is very similar within the Federal Act and the Flemish Decree. There are a couple of requirements concerning the request. Whilst the Federal Act deals with the application procedure in one article ${ }^{57}$ the Flemish Decree contains a separate section for the application procedure. ${ }^{58}$ Firstly we will discuss the procedure within the Federal Act.

Access to information is granted upon request. There are a couple of requirements concerning the request. First of all a request must be written. ${ }^{59}$ The term 'written' is interpreted broadly nowadays but typically covers letters, emails, faxes and web forms. ${ }^{60}$ Practical reasons are the basis for the requirement of a written request. Administrative authorities are free to give effect to a

\footnotetext{
49 Art. 1, par. 2, $2^{\circ}$ Federal Act of 11 April 1994.

See for example: Council of State 21 May 2001, no. 95.677, Antoun in which the Council of State judged that a software program concerning the electronic voting is an administrative document.

50 Explanatory memorandum preceding the Federal Act of 11 April 1994 concerning access to administrative documents, Parl. St. Kamer 1992-93, no. 1112/1, 11 and Report on behalf of the commission of internal affairs, general affairs and the civil service, Parl. St. Kamer 1992-93, no. 1112/13, 9.

51 Explanatory memorandum preceding the Federal Act of 11 April 1994 concerning access to administrative documents, Parl. St. Kamer 1992-93, http://www.ibz.rrn.fgov.be/n1/commissies/openbaarheid-van-bestuur/adviezen/

Art. $3,4^{\circ}$ Flemish Decree of 26 March 2004.

See also TIJS (2011) pp. 81-82.

See SCHRAM (2011), pp. 681.

Art. 8 Flemish Decree of 26 March 2004.

Explanatory Note Flemish Decree of 26 March 2004, 21-22.

Art. 5 Federal Act of 11 April 1994.

Section IV. The request procedure (art. 17-21) Flemish Decree of 26 March 2004

Art. 5 Federal Act of 11 April 1994.

See SCHRAM (2011), pp. 689
} 
request made by phone but in this case the right of appeal is not guaranteed. ${ }^{61}$ Secondly, the request must clearly mention the relevant issue and where possible, the relevant administrative documents. Finally, the request has to be addressed to the competent federal administrative authority. If however, the request is addressed to a federal administrative authority who does not have the document in its possession, the authority has an obligation to refer the applicant to the relevant authority. ${ }^{62}$ Specifically for administrative documents of a personal nature it is further required that the applicant proves that he has an interest. For all other documents the applicant can make a simple request, without having to show an interest. ${ }^{63}$

Also like in the Federal Act, the Flemish Decree requires that the request has to be in writing. This means that the request can be filed by letter, by fax or by email. Moreover, the request can also be made oral on site. In this case, the applicant has to fill in a form. If necessary, a staff member will assist the applicant herein. An oral request by phone on the other hand is not possible. ${ }^{64}$ Regarding the content of the request, the request must clearly state the issue concerned, and if possible the relevant executive documents, as well as the name and the correspondence address of the applicant. The latter requirement is only necessary to allow the instance to give an answer to the applicant. For this purpose an email address is sufficient. ${ }^{65}$ This was in practice criticised as it gives no guarantee on the identity of author of the request. The applicant should also mention the preferred carrier in which the information is provided. ${ }^{66}$ However this is a non-mandatory requirement. ${ }^{67}$

The applicant has to prove his identity and, where applicable, the fact that he received the consent of the person from who the information derives, if the request concerns the private life, confidential commercial or industrial information or information provided by a third party without being obligated thereto and which is explicitly labelled confidential by the third party. ${ }^{68}$ Only in the case of information of personal nature, the applicant has to show an interest. ${ }^{69}$

Finally, the request has to be addressed to the instance who possesses the document. If however the instance who receives a request does not have the concerned documents, the instance must forward the request as soon as possible to the instance who probably possesses the documents. The instance also informs the applicant thereof. ${ }^{70}$ This is a difference with the Federal Act which only obligates the administrative authority to refer the applicant to the authority who is in the possession of the document without actively forwarding the request to that authority.

If the request is manifestly unreasonable ${ }^{71}$ or formulated in a too general manner, as soon as possible the authority must ask the applicant to complete his application or to reformulate it in a more specific manner. The authority informs the applicant why the application is manifestly unreasonable or formulated too generally (see later when we discuss exceptions). To the extent possible, it should also be indicated which information is required about the information requested in order to be able to comply with the application. ${ }^{72}$

4.2. The response or answer of the administrative authority

The administrative authorities must take a decision to grant or reject access to documents within a certain period. The Federal Act contains a provision which explicitly states that the authority should answer the request within a period of 30 days after

1 Explanatory Note Federal Act of 11 April 1994, 14.

62 Art. 5 Federal Act of 11 April 1994.

63 Art. 4 Federal Act of 11 April 1994; Explanatory Note Federal Act of 11 April 1994, 13-14; Council of State 7 May 2007, no. 170.871, Rummens; Constitutional Court 25 March 1997, no. 17/97.

64 Art. 17, §1, first paragraph Flemish Decree of 26 March 2004; Explanatory Note Flemish Decree of 26 March $2004,34$.

65 Ibid; see also Flemish Appellate Body on the Openness of Government 30 September 2015, no. 170/2015 and Flemish Appellate Body on the Openness of Government 14 December 2015, no. 207/2015.

66 Art. 17, §1, second paragraph Flemish Decree of 26 March 2004.

67 The explanatory note clearly states that 'the applicant can indicate the preferred form'. This means that the applicant has an option to choose the preferred form of the carrier (written, electronic) and the format of the electronic carrier. Explanatory Note Flemish Decree of 26 March $2004,35$. See also SCHRAM (2013), pp. 83.

68 Art. 17, §1, third paragraph Flemish Decree of 26 March 2004.

69 Art. 17, \$2 Flemish Decree of 26 March 2004

Art. 17, \$3 Flemish Decree of 26 March 2004

1 When the request involves too many documents and aims solely to harass the authorities.

Art. 18 Flemish Decree of 26 March 2004. 
receiving the request, which may be extended by a maximum of 15 days. ${ }^{73}$ Both the decision to grant or to reject access has to be motivated. If no decision has been taken within this specified period, the request shall be deemed rejected. ${ }^{74}$

The Flemish Decree contains a stricter timing: "the application must be responded to as soon as possible and at the latest within 15 calendar days, either in writing, by fax or by e-mail". ${ }^{75}$ If the application is manifestly unreasonable or formulated in a too general manner, a new 15-day term begins from the time when the applicant has completed or (re)formulated his application more specifically. ${ }^{76}$ If the information requested is difficult to collect in a timely fashion or if the verification of the application for making public as regards the exceptions is difficult to complete in time, then the authority must inform the applicant that the term is extended to thirty calendar days. ${ }^{77}$ If no formal decision is taken by the authority, the request shall be deemed rejected. ${ }^{78}$ Whereas if the authority grants access to the applicant, this decision will be effected as soon as possible and the latest within thirty calendar days. ${ }^{79}$

In a pending legislative proposal with the Federal Chamber a number of changes are proposed to the Federal Act on transparency. The petitioners want to introduce more strict terms for the administrative authorities to answer the request. The terms would be made uniform with the existing terms under the Flemish Decree. ${ }^{80}$

\section{Excepted information}

Not all applications to get access to administrative documents can be granted by the authorities. In some cases the right of access can be denied. In general there are three kinds of exceptions: (i) relative mandatory exceptions; (ii) absolute mandatory exceptions and (iii) optional exceptions by which the authority can choose whether or not to apply the exception. Common to all these exceptions is that partial disclosure takes precedence over an overall refusal to provide access to an administrative document. ${ }^{81}$ By the mandatory exceptions the authority is obliged to reject access if the exception is applicable. All three groups of exceptions have to be interpreted restrictively. ${ }^{82}$

\subsection{Exceptions within the federal framework}

Article 6 of the Federal Act contains the exceptions on granting access to administrative documents. Although both the first and the second group of exceptions are mandatory, there is a difference in the appreciation of the exceptions. The first group of exceptions are relative, whereas the second group of exceptions are absolute. Absolute exceptions lead to a refusal of the request if the protected interest is affected even to the slightest degree, whereas relative exceptions only lead to a refusal if the protected interest prevails over the interest of disclosure. In the case of relative exceptions the administrative authority therefore has a margin of discretion in determining which interest prevails. ${ }^{83}$

However, the administrative authority always has to examine whether there is a real risk for the protected interest (in the case of absolute exceptions) or whether the protected interest prevails over the interest of disclosure (in the case of relative

\footnotetext{
73 The period can be extended for example when the document is located elsewhere in an archive (Explanatory note accompanying the legislative proposal of the government to implement an article 24ter in the Constitution concerning access to administrative documents, Parl. St. Kamer 19921993, no. 839/1, 18).

4 Art. 5 Federal Act of 11 April 1994

5 Art. 20, \$2 Flemish Decree of 26 March 2004

The terms of the decisions and execution begin on the day after the date of registration of the application, and in the event of no such registration having taken place, on the day after the date of receipt of the application (art. 6 Flemish Decree of 26 March 2004).

77 Art. 20, §2 Flemish Decree of 26 March 2004.

See infra administrative and judicial remedies for the importance of taking a decision by the authority.

Art. 20, §3 Flemish Decree of 26 March 2004.

Legislative proposal to amend the Act of 11 April 1994 on access to administrative documents, Parl. St. Kamer 2014, no. 0061/001, 5.

Art. 6, §4 Federal Act of 11 April 1994; art. 9 Flemish Decree of 26 March 2004.

82 Explanatory Note Federal Act of 11 April 1994, 16. For an example see: Council of State 14 April 2009, no. 192.371, Nationale Instelling voor radioactief afval en de verrijkte splijtstoffen; Constitutional Court 25 March 1997, no. 17/97, B.2.1. and B.2.2.; Constitutional Court 15 September 2004, no. 150/2004, B.3.2.

83 See MAST, DUJARDIN, VAN DAMME and VANDE LANOTTE (2014), pp. 911; see also SCHRAM (2011), pp. 691.
} 
exceptions). ${ }^{84}$ This means that an exception cannot be applied automatically. The administrative authority must investigate each request upon the applicability of exceptions and motivate in concrete why access cannot be given. ${ }^{85}$ The federal Commission on Access to and Reuse of Administrative Documents states that three conditions have to be fulfilled to invoke these relative exceptions: (i) a particular interest is mentioned which is considered worthy of protection by the law; (ii) disclosure would harm the protected interest; (iii) the importance of the disclosure does not weigh more heavily than the damage caused to the protected interest. ${ }^{86}$

In the first group, the administrative authority, federal or other, rejects a request for access to an administrative document if the interest of disclosure does not prevail over one of the following general interests: ${ }^{87}$ public safety; fundamental rights and freedoms of the citizens; ${ }^{88}$ the federal international relations of Belgium; the public order, the safety or the defence of the country; the investigation or prosecution of criminal facts: a federal economic or financial interest, the currency or the public credit rating ${ }^{89}$ the confidential nature of the company data or manufacturing data that are communicated to the authorities and finally the secrecy of the identity of a person who has entrusted a document or information to an administrative authority of a criminal fact or a criminal deemed fact ${ }^{90}$.

According to the second group of exceptions, the administrative authority, federal or other, rejects a request for access to an administrative document if the interest of disclosure endangers one of the following specific interests: ${ }^{91}$ private life $;{ }^{92}$ secrecy established by law; ${ }^{93}$ secrecy of federal government deliberations and of collegial authorities that depend on the federal executive power or whereby a federal authority is involved and the interests as mentioned in article 3 of the law of 11 December 1998 concerning the classification, the security authorisations, the security certificates and the security advices.

Some case law can clarify the distinction made between the relative mandatory and the absolute mandatory exceptions. In 2000 the federal government rejected a request from Filip Dewinter, a right-wing Belgian politician, to gain access to his personal file by the State Security Service. The federal government invoked two mandatory exceptions to justify this refusal: a relative one (the public order, the safety or the defense of the country) and an absolute one (private life). The consultation of the file would, following the authority, disclose the modus operandi of the Security Service and constitutes an infringement on the privacy of third parties (staff members, informants, address of headquarter,...). The Belgian Council of State reiterates that transparency is the rule and that exceptions must be interpreted restrictively. Firstly, the federal government doesn't show in its balancing of interests why the public order or safety of the country must prevail above the access of public documents. Secondly, concerning the absolute exception of the private life, the Council of State notes that the information on the modus operandi of the Security Service and third parties can be made unreadable (partial disclosure). ${ }^{94}$

The third group of exceptions allows the administrative authority to reject a request for access to an administrative document for mainly practical administrative reasons. A federal administrative authority may reject a request insofar as the request: ${ }^{95}$ concerns an unfinished or incomplete administrative document whose disclosure may lead to misunderstandings; concerns an advice or an opinion which is communicated to the authority on a voluntarily and confidential basis ${ }^{96}$; is clearly unreasonable or is clearly too vague. A federal administrative authority may reject a request if the request is deemed unreasonable. This

84 Council of State 8 January 2004, no. 126.934, Barbé.

85 Explanatory Note Federal Act of 11 April 1994, 15-16. See for example: Council of State 15 May 2014, no. 227.394, cvba Belgische Verbruikersunie Test-Aankoop; see MAST, DUJARDIN, VAN DAMME and VANDE LANOTTE (2014), pp. 912; see also SCHRAM (2011), pp. 691.

86 ANDERSEN (1999), pp. 38.

87 Art. 6, \$1 Federal Act of 11 April 1994

88 An example where the request does not prevail over the fundamental rights and freedoms of the citizens, is in the case of the protection of the rights of patients (Council of State 10 January 2013, no. 221.961, cvba Belgische Vebruikersunie Test Aankoop.)

9 Council of State 18 June 1997, no. 66.860, Matagne.

For example the identity of an informant in fiscal or criminal cases: Council of State 27 June 2001, no. 97.056, Tassin.

Art. 6, §2 Federal Act of 11 April 1994.

The exception with regard to the protection of private life is not applicable in the case that consent is given by the person involved.

For example the professional secrecy of a lawyer: Council of State 29 January 2009, no. 189.864, Gemeente Lochristi.

Council of State 11 December 2000, no. 69.056, Dewinter.

Art. 6, §3 Federal Act of 11 April 1994.

Council of State 7 June 2004, no. 132.072, Lybaert. 
discretionary exception is registered to guarantee the normal functioning of the public service. ${ }^{97}$ In a case of 2014 , the Federal Agency for the Safety of the Food Chain rejected, by invoking this exception, the access to a checklist for the inspection of Pita Restaurants and to a database to consult information. The reason for the rejection was the excessive workload for granting access to these documents. The Council of State reiterates that the right for access to documents maintains a positive obligation for the public authorities to which they must comply. They must organise themselves in a way that requests to get access can be granted. In case that they rejected access the authority must motivate the rejection concretely.

The following motive of the Federal Agency for the Safety of the Food Chain was, following the Council of State, inadequate: "Given the fact that we need all our people to perform our core business, which is to ensure the safety of the food, we maintain our view to reject the application because of its unreasonable character." This is a pure style formula, consisting of generic terms without a substantive capacity, which is insufficiently individualised and not specifically focused on the organisation for the Federal Agency. ${ }^{98}$ In other words, the discretionary exceptions must be motivated with concrete relation to the authority which invokes the exception. In another case, an application for access to a study about a military hospital was rejected. The Department of Defense invokes the exception that it concerns an advice or an opinion which is communicated to the authority on a voluntarily and confidential basis, which is a discretionary exception. ${ }^{99}$ After the advice of the Commission, the Department confirmed its earlier decision not to disclose the study. The Council of State judged that the study wasn't communicated on a voluntarily basis, as the director of the Military Hospital instructed specifically to make a study. An examination of the facts is always necessary to check the decision to reject. ${ }^{100}$

When a citizen requests to consult thousands of objections following a master plan of a government and also requests getting copies of it, this request for copies can be considered as being unreasonable. The consultation is possible, but the request for copies is unreasonable.

Last but not least -not explicitly regulated-an authority can reject a request if the requested document does not exist.

\subsection{Exceptions within the Flemish framework}

Just like in the case of the Federal Act, the Flemish Decree comprises three kinds of exceptions: optional exceptions, relative mandatory exceptions and absolute mandatory exceptions. Besides of the exceptions provided for in the Decree, there can also be exceptions set out in specific law, decrees or ordonnances. ${ }^{101}$ Furthermore an instance can also reject a request concerning a document that does not (yet) exist.

The absolute mandatory exceptions, stipulate that the instances decline a request if the disclosure infringes an obligation of secrecy establishes in a matter for which the community or the region is competent; if the disclosure infringes the protection of private life, except if consent is given by the concerned person; ${ }^{102}$ if the disclosure infringes the secrecy of deliberations of the Flemish government and of collegial authorities and the secrecy of deliberations of bodies of the Flemish Parliament as well as secrecy establishes by law or decree of bodies of the instances mentioned in article $4, \S 1,3^{\circ}-10^{\circ}$; if the request concerns executive documents that were solely set up for the purpose of a criminal prosecution or the prosecution of an administrative sanction; if the request concerns executive documents that were solely set up for the purpose of disciplinary measures, in so far as the possibility to take a disciplinary measure exists and finally if the request concerns executive documents which contain

Explanatory Note Federal Act of 11 April 1994, 19

Council of State 15 May 2014, no. 227.394, CVBA Belgische Verbruikersunie Test-aankoop.

Art. 6, §3 Federal Act of 11 April 1994

100 Council of State 29 March 2010, no. 202.459, Sevenhans.

101 Art. 12 Flemish Decree of 26 March 2004

102 For example: In the procedure before granting a permit, objections can be made by citizens. A request for disclosure of these objections may conflict with the right to privacy. The decision to reject access to the identity of the submitter of the objections is justified under the exception of the protection of privacy (Flemish Appellate Body on the Openness of Government, no. 2007/23. 
information provided by a third party without being obligated thereto and if the information is explicitly labelled as confidential, except if the third party has given his consent to the disclosure. These exceptions have to be applied by all instances and not only the instances within the Flemish community or the Flemish region. ${ }^{103}$

The relative mandatory exceptions also have to be applied by all instances. In this case, the instances have to decline a request for access to information if they decide that the interest of disclosure does not prevail over one of the following interests: an economic, financial or commercial interest of an instance mentioned in article 4, $\$ 1$; the confidential character of the international relations of the Flemish community or the Flemish region and the relations of the Flemish community or the Flemish region with supranational institutions, the federal government and the other communities and regions; the confidential character of commercial and industrial information, when this information is protected in order to preserve a legitimate economic interest, except if the person who provided the information gives his consent to the disclosure; the legal procedure in a civil or administrative lawsuit and the possibility of a fair trial; the confidentiality of the actions of an instance in so far as the confidentiality is necessary for the pursuit of the administrative enforcement, the execution of an internal audit or the political decision making and lastly the public order and security. ${ }^{104}$

Finally, the optional exceptions of the Flemish decree can only be applied by the instances within the Flemish community and the Flemish Region. These instances can, besides the exceptions that were mentioned previously, decline a request if the request is clearly unreasonable or too vague. However this exception can only be invoked after a request has been made by the instances to the applicant to specify or complete his request as soon as possible. The instance states the reasons why the request is clearly unreasonable or too vague and, if possible, indicates which data concerning the requested information are necessary to be able to grant the request. If the request remains clearly unreasonable or too vague afterwards, the instance can decline the request. ${ }^{105}$ Secondly, the instance can decline a request concerning an unfinished or incomplete executive document. ${ }^{106}$ This last point was illustrated when a citizen of Tienen wanted access to a monthly report of a not for profit organisation which stimulated the commerce in a city. As long as the monthly report has to be approved at the first meeting then this document could not be considered as a final document. A refusal to get access is within that period justified. ${ }^{107}$ Also a draft decision of a building permit cannot be considered as a finished administrative document. The disclosure can be rejected, because of the fact that the administration itself doesn't decide on the building permit. The final decision has to be taken by a competent body (municipality, province or Flemish Government), only after the signing of the decision it will be considered as a finished administrative document. ${ }^{108}$

The Council of State clarified ${ }^{109}$ in its case law the concept as follows: an administrative document obtains a final status - and falls under public control - if this document is formally endorsed by the service in question, even if the document is subsequently subject to change.

The fact that no interest is required to get access to documents doesn't contain a permission to submit systematically applications and so interrupting the normal operation of the public authority. Therefore, repeated applications may constitute an abuse of the law on disclosure and can be classified as unreasonable applications in the sense of article $11,1^{\circ}$ of the Flemish

103 Art. 13 Flemish Decree of 26 March 2004

104 Art. 14 Flemish Decree of 26 March 2004

See for example the Case of the Flemish Appellate Body on the Openness of Government no. 2008/146: a rejection was based on the economic interest of the government. In casu the information consisted of estimates that were used during negotiations on the purchase of land.

105 Art. $11,1^{\circ}$ and art. 18 Flemish Decree of 26 March 2004.

106 Art. $11,2^{\circ}$ Flemish Decree of 26 March 2004.

107 Flemish Appellate Body on the Openness of Government 4 March 2008, no. 2008/11 (available at: openbaarheid.vlaanderen.be).

108 Example of the exception mentioned in article 11, $2^{\circ}$ of the Flemish Decree 26 March 2004.

109 Council of State 28 juni 2011, nr. 214236, Provincie Oost-Vlaanderen 
Decree. However the Flemish Appellate Body on the Openness of Government argues that this is a delicate and difficult question to answer. In assessing the reasonableness of the application, different factors should take into account: (i) the amount of applications and (ii) the time period within which the various applications are submitted. ${ }^{110}$

To further clarify the above mentioned exceptions some examples to illustrate the problems and discussions in practice:

A first remarkable case concerning transparency was the case of Nils Dumortier against the Flemish Community. ${ }^{111}$ Nils Dumortier, a Belgian student in journalism who did research on transparency for his thesis, requested access in the salaries of every person mentioned in the organogram of the VRT, the Flemish Radio- and Television Organisation. The VRT rejected access to this information by arguing that releasing salaries of top managers must be rejected as this would violate the privacy of the employees or the managers. Moreover, the disclosure of such information would not outweigh the economic, financial or commercial interest of the VRT. ${ }^{12}$ Disclosure of the salaries would also cause harm to future wage negotiations of the VRT with existing or newly recruited staff members. The VRT also argued that there exists no legal framework for the publication of salaries of top managers in Flemish institutions. Dumortier appealed the decision of the VRT with the Flemish Appellate Body on Open Government. The appellate body confirmed the decision of the VRT, by arguing that the invoked exceptions by the VRT were justified and sufficiently motivated.

Dumortier lodged an appeal before the Council of State to annul the decision of the appellate body. He argues that the VRT made no concrete motivation that the disclosure prejudices the protection of individual privacy. The fact that the privacy exception is an absolute mandatory exception doesn't mean that the VRT can invoke this without any in concreto motivation. With regards to the exception of economic, financial or commercial interest the applicant (Dumortier) argued that the VRT hasn't made a balance of interests. They have not shown that the economic, financial or commercial interest transcends the interest of disclosure. The VRT argues that it operates in a competitive media landscape in which the disclosure of information concerning the remuneration if its staff would provide an unfair advantage of its competitors by trying to persuade VRT staff to come working with them. Especially due to the fact that their competitors do not fall within the scope of the Flemish Decree.

The Council of State reiterates that every exception has to be motivated in concrete with reference to specific circumstances of the case. The Council of State assumes that salary information belongs to the privacy of an individual. However, this mere statement is not sufficient to invoke the exception. The VRT doesn't prove why disclosure would violate the privacy. The invoked exception doesn't stand for not granting access to the salaries of the members of the organogram of the VRT. The second exception, namely the economic, financial or commercial interest is also not applicable in this case. The general interest may never be lost sight when invoking an exception. It is in the general interest that the tax payers are informed about the use of government revenues, including staff costs. The Council of State annulled the decision of the VRT and the Flemish Appellate Body. The annulation by the Council of State has not as a consequence that the salaries has to be made public. It only requires that a new investigation of balance of interests must be made and that, if the VRT wants to invoke exceptions, the exceptions must be motivated in concrete.

A second interesting case concerns a citizen that, in 2008 requested a copy of a study entitled 'The legal status of watermills' commissioned by the Department of Environment, Nature and Energy. The disclosure of the study was partially rejected by the Department. The citizen appealed both the partial refusal and the failure to implement the decision of partial disclosure. The Department argued that the implementation has not yet been completed because the study must be censored first and the screening of the full report is an extensive job and is totally not a priority. The Flemish Appellate Body judged that the Department fails to fulfil its legal obligations imposed by the Flemish Decree concerning open government. In general, a fast

110 Flemish Appellate Body on the Openness of Government 18 April 2011, no. 2011/56 (available at: openbaarheid.vlaanderen.be); Flemish Appellate Body on the Openness of Government 14 January 2010, no. 2009/176.

111 Council of State 2 May 2016, no. 234.609, Dumortier.

112 The VRT invoked the exceptions of article 13, $2^{\circ}$ and $14,1^{\circ}$ of the Flemish Decree of 26 March 2004. 
implementation of the decision to disclosure is required. For only disclosing the study partially, the following exceptions were invoked by the Department: "confidentiality of the actions of an authority insofar as this confidentiality is required for the political decision-making process". ${ }^{113}$ The study itself would in no way develop policies, but only provide information to come to an integrate policy about watermills. The Appellate Body examined whether the interest on disclosure is outweighed by the protection of the confidentiality of the actions of the authority, insofar this confidentiality is required for the political decisionmaking process. ${ }^{114}$ The study only covers a judicial view on an integrated policy on water mills and dated two years before the application. Within these two years, the study has not yet led to concrete policy proposals. The proposals mentioned in the study do not form part of any political decision-making process. For these reasons the study should be fully released.

A third case concerns also a dispute over whether or not partial release of information, in particular a whole series of minutes from the Port Authority and this over a long period. ${ }^{115}$ The decision of the Appellate Body was appealed because he had judged in line with the initial refusal decision that the request was unreasonable in the meaning of article $11,1^{\circ}$ of the Flemish Decree.

The decision considered the substantial volume of documents and the fact that these document always have to be checked for possible exceptions. It was considered that not with the required caution, the volume was determined for the requested documents. The refusal of the fundamental right to disclosure pursuant to a quantitative criterion dictates the greatest caution satisfied according to the Council of State. The screening of the minutes is a massive task, but it does not appear that this task should be considered as insurmountable. In this case, the information was requested from a large and forceful administrative authority, which may be expected that it knows how to organize to meet disclosure to the question.

A fourth case concerns a small local community where minutes were also requested. The complainant alleged that the minutes had to be released in whole, at least partially. It was up to the concerned community to take the necessary steps, and if necessary, to take the information that was protected by privacy. The Appellate Body declared the appeal unfounded: "Whereas the production in the minutes of aldermen a whole list of topics will be discussed: individual planning cases, individual environmental permits, decisions concerning immovable property owned by individuals, individual staff files of officials, administrative sanctions, different social allowances to individuals, exam results, subscriptions and removing of population register... and that they really intertwined of information and entries regarding the privacy of an individual; that the municipal administration for the requested minutes should have to examine the extent to which certain parts of the minutes can't be public, for the protection of the privacy; that this pieces then have to be made each unreadable before a copy can be provided to the applicant; that this is a heavy administrative task for an administrative authority, that would have as a result that barely legible signed documents remain in the minutes; Concerning that the 'cleansing' of the minutes (more than 20 pages by meeting) of the personally information in that case has no sense and that disclosure of the requested documents must be rejected in this case, referring to the application of article $13,2^{\circ}$ Flemish Decree and the protection of privacy of a whole range of individuals; Concerning that the action with regard to this (minutes of aldermen), must be regarded as unfounded. "116 The Council of State held similarly in another case ${ }^{117}$ that the principle of partial disclosure and separation of the information contained in article 9 of the Flemish Decree is not absolute. The argument of the applicant that 'in practice (...)to separate [is] always possible by blackening certain passages", cannot accepted. In the present case it was sufficient for the Council of State to declare that "the applicant submits no further elements which could justify a partial disclosure of the documents in the file." The infringement was therefore rejected.

113 Art. $14,5^{\circ}$ and art. $15,5^{\circ}$ Flemish Decree of 26 March 2004.

114 The term 'political decision-making process' has to be interpreted strictly (Explanatory Note Flemish Decree of 26 March 2004, 31 ).

115 Council of State 21 November 2014, nr. 229.270, Katoen Natie, e.a.; see also Council of State 8 november 2016 nr. 236.367.

116 Flemish Appellate Body on the Openness of Government 12 July 2013, no. 2013/90. Contra case 2015/82 the Appellate Body argued that (full) refusal was not allowed and that the local authority had to blacken words/sentences as to allow a partial disclosure.

117 Council of State 24 June 2014, no. 227.809, Verrycken. 


\section{Special regime for the access to environmental information}

The reason for a separate legislation about environmental information lies in the implementation of the Convention of Aarhus and Directive 2003/4/EC of 28 January 2003 on public access to environmental information. The implementation is done in different manners depending on the legislative level. On the federal level and in the Brussels Region there are separated laws regarding environmental information. On the Flemish level the access to environmental information is integrated in the general decree regarding access to information. In the Walloon Region it is integrated in the Environmental Code.

On the federal level, specific regulation was adopted to deal with the access to environmental information, namely the act of 5 August 2006 concerning the access to environmental information. ${ }^{118}$ It was the intention of this Act to guarantee a right of access to environmental information held by (federal) public authorities and to establish the rules and practical arrangements for exercising that right. The reason for a different legal instrument on Federal level and not on the Flemish level is easily explained. The law represents a conversion of Directive 2003/4/EG, while the Flemish Decree was adopted after the publication of the Directive and automatically could include these principles in its general Decree.

The Federal legislator opted not to use the term 'administrative authority' to define the scope ratione personae of the Act of 5 August 2006. The law determines three categories of 'environmental bodies': (i) a legal person or body established by the Constitution, a law, a decree or a rule referred to in Article 134 of the Constitution; (ii) a natural or legal person performing public administrative functions, including specific duties, activities or services in relation to the environment and (iii) a natural or legal person under the control of a body or person referred to in (i) or (ii) responsible for providing public services relating to the environment. ${ }^{119}$

The Aarhus Convention defines in detail what is covered by the term 'environmental information'. It includes for example: the state of the elements of the environment, environmental agreements, human health and safety, including any contamination of the food chain, $\ldots{ }^{120}$ The Flemish Decree defines 'information on the environment' as information about the environment; measures and activities that lead or may lead to pressure on the environment; nature, building and areas of cultural beauty, the health, safety and living conditions of the population and the impact on these,..${ }^{121} \mathrm{~A}$ same definition is mentioned in the federal legislation. ${ }^{122}$

With regards to the Flemish appeal procedure for access to environmental information, we can refer to the general discussion (infra 7.). On the federal level the appeal procedure is different for environmental information then for non-environmental information. The Federal Act of 5 August 2006 established a specific appellate body for environmental information, namely the Federal Appellate Body on the Access to Environmental Information. ${ }^{123}$

The most important difference in the field of environmental information is the exceptions established by the Federal Act of 5 August 2006 and the Flemish Decree of 26 March 2004. Not all the exceptions for the general documents can be applied for 'environmental documents'.

Under the Federal Act there only two exceptions which have an absolute mandatory character: when the request is manifestly unreasonable or when the request remains formulated in a too general manner after the authority has requested the reformulation of the first application. ${ }^{124}$ A request can be considered unreasonable if it requests the disclosure of the entire international,

118 Federal Act of 5 August 2006 concerning the access to environmental information, BS 28 August 2006, 42538.

119 Art. $3,1^{\circ}$ Federal Act of 5 august 2006; Explanatory note accompanying the Federal Act of 5 August 2006 concerning the access to environmental information, Parl. St. Kamer 2005-2006, no. 2511/001, 12-13.

120 See Aarhus Convention and EU Directive 2003/4/EC of the European Parliament and of the Council of 28 January 2003 on public access to environmental information and repealing Council Directive 90/313/EEC, Pb. L. 14 February 2003, 41/26.

121 Art. 3, $5^{\circ}$ Flemish Decree of 26 March 2004

122 Art. $3,4^{\circ}$ Federal Act of 5 August 2006

123 Art. 33-42 Federal Act of 5 August 2006

124 Art. 32, §2 Federal Act of 5 August 2006. 
European and national environmental framework. ${ }^{125}$ Under the Flemish Decree these exceptions remains also for the environmental information only optional. ${ }^{126}$

In the grounds for exceptions for 'general information' a difference is made between the relative and absolute mandatory exceptions, this difference doesn't exist for environmental information (except in the two federal cases mentioned above). By invoking an exception to reject access to environmental information the administrative body must always check if the protected interest prevails over the interest of disclosure. ${ }^{127}$ The exceptions mentioned in the Federal Environmental Act are identical to those in the Flemish Decree: (i) the protection of individual privacy, unless the person concerned consents to the making public; ${ }^{128}$ (ii) the confidentiality of the deliberations of the Flemish/federal government and of the responsible bodies that depend from it; ${ }^{129}$ the confidential nature of administrative documents that where compiled exclusively for criminal or administrative penalty proceedings; ${ }^{130}$ the protection of information provided by a third party without this party being compelled or obliged to do so, and which the said party has explicitly designated as confidential, unless this persons consents to the making public; ${ }^{131}$ the confidential nature of the international relations of the government; ${ }^{132}$ the confidential nature of commercial and industrial information, when this information is protected to safeguard a legitimate economic interest, unless the party from whom the information originates agrees to the public nature thereof; ${ }^{133}$ the dispensation of justice in civil or administrative proceedings and the possibility to obtain a fair trial; ${ }^{134}$ public order and safety ${ }^{135}$ and the protection of the environment the information relates to. Further, the Flemish Decree contains two exceptions which are not mentioned in the Federal Environmental Act: (i) the confidential nature of administrative documents compiled exclusively for the possible implementation of disciplinary measures, for as long as the possibility of a disciplinary measure continues ${ }^{136}$ and (ii) the confidentiality of the actions of an environmental authority insofar as this confidentiality is required for administrative enforcement, the performance of an internal audit or the political decision making process. ${ }^{137}$ To the extent the requested information concerns emissions; some grounds for exception do not apply in both the Federal Act and the Flemish Decree. ${ }^{138}$ To conclude, some grounds for exceptions are absolute mandatory for 'general information', but are relative mandatory for the environmental information.

\section{Administrative and judicial remedies}

Both the Federal Act and the Flemish Decree contains provisions regarding an appeal procedure when the application for access to documents is explicitly or implicitly rejected or in the event of the decision being carried out reluctantly. ${ }^{139}$ They both stipulate the obligation to mention the remedies and modalities of the specific administrative appeal procedure in the decision sent to the person(s) concerned. A non-observance of that obligation has the effect that the term to introduce a complaint is not running. ${ }^{140}$ This will only be running four months after the person was notified of the act or decision of individual application. When under the Federal Act on Transparency the right of access is rejected, a complex administrative appeal procedure is available. In such a case the applicant must address a question for reconsideration to the authority that has rejected the access

125 See SCHRAM (2010), pp. 113

126 Art. 11 Flemish Decree of 26 March 2004

127 Art. 27 Federal Act of 5 August 2006; art. 15 Flemish Decree of 26 March 2004.

128 Art. 15, $\$ 1,1^{\circ}$ Flemish Decree of 26 March 2004; art. 27, $\$ 1,1^{\circ}$ Federal Act of 5 August 2006

129 Art. 15, $\$ 1,2^{\circ}$ Flemish Decree of 26 March 2004; art. 27, $\$ 1,6^{\circ}$ Federal Act of 5 August 2006

130 Art. 15, $\S 1,3^{\circ}$ Flemish Decree of 26 March 2004; art. 27, $\$ 1,{ }^{\circ} 4$ Federal Act of 5 August 2006.

131 Art. 15, $\$ 1,5^{\circ}$ Flemish Decree of 26 March 2004; art. 27, $\$ 1,8^{\circ}$ Federal Act of 5 August 2006

132 Art. 15, $\$ 1,6^{\circ}$ Flemish Decree of 26 March 2004; art. 27, $\$ 1,3^{\circ}$ Federal Act of 5 August 2006

133 Art. 15, $\$ 1,7^{\circ}$ Flemish Decree of 26 March 2004; art. 27, $\$ 1,7^{\circ}$ Federal Act of 5 August 2006

134 Art. 15, $\S 1,1^{\circ}$ Flemish Decree of 26 March 2004; art. 27, $\$ 1,1^{\circ}$ Federal Act of 5 August 2006

135 Art. 15, $\$ 1,10^{\circ}$ Flemish Decree of 26 March 2004; art. 27, $\$ 1,2^{\circ}$ Federal Act of 5 August 2006

The Federal Act gives two examples: the physical protection of radioactive materials and the defense of the country.

136 Art. $15, \S 1,4^{\circ}$ Flemish Decree of 26 March 2004.

137 Art. 15, $\$ 1,9^{\circ}$ Flemish Decree of 26 March 2004

138 Art. 15, §2 Flemish Decree of 26 March 2004; art. 27, §2 Federal Act of 5 August 2006.

139 Art. 8, §2 Act of 11 April 1994; art. 22 Flemish Decree of 26 March 2004.

140 Art. 2, $4^{\circ}$ Act of 11 April 1994; art. 35 Flemish Decree of 26 March 2004. 
and simultaneously address a question for advice to the Commission for Access to Administrative Documents. ${ }^{141}$ Within a period of 30 days the Commission shall report to the denying authority a non-binding advice to grant or to reject the access. Finally, the initial administrative authority takes the final decision within 15 days after the advice or after the expiry of the term to give advice. ${ }^{142}$ If no decision is made within this period, it is assumed that the authority has taken a decision to reject access. ${ }^{143}$ This is an organised administrative appeal, because the law explicitly provides for an administrative appeal. The fact that the appeal is organized, determines the competences of the Council of State. ${ }^{144}$ Before a complaint can be made before the Council of State, the organised administrative appeal must be exhausted. The period for going in appeal with the Council of State is normally 60 days, unless when no decision is taken or of the appeal possibilities are not mentioned in the decision. In these circumstances, the period only starts 4 months after the decision was brought to the attention of the applicant.

In comparison with the Federal Act, the Flemish Decree established a new body of appeal: the Flemish Appellate Body on the Openness of Government. It is not a request for reconsideration with the same body, but an appeal with another body against the earlier decision. The appeal of the applicant must be in writing, by letter, by fax or by email and must be submitted within a period of 30 calendar days. ${ }^{145}$ The appellate body adjudicates on the appeal and notifies its decision to the applicant within a period of 30 calendar days. ${ }^{146}$ In the case that the appellate body doesn't grant access, the applicant can lodge an appeal before the Council of State within 60 days. In the past 12 years only 55 cases were lodged before the Council of State regarding the Flemish Decree on open government. 39 of the cases were already judged by the Council of State, which only (partially) annulled nine decisions of the Flemish Appellate Body. ${ }^{147}$ The low number of requests to the Belgian Council of State constitutes a solid argument in the direction of effectiveness of the administrative appeal. ${ }^{148}$

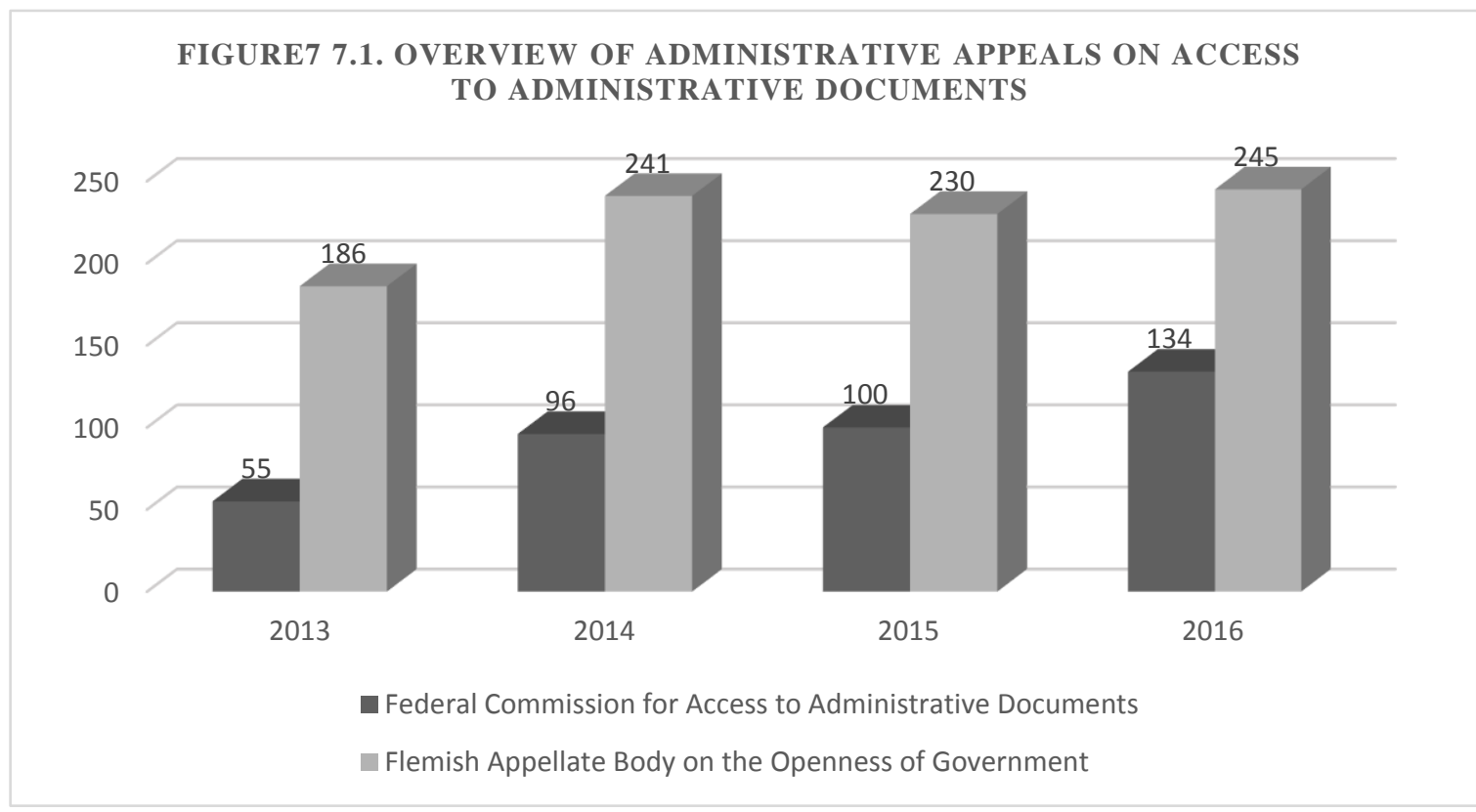

141 Art. 8 Act of 11 April 1994.

142 If the advice is not made within this period, then the administrative authority can decide without the advice.

143 Art. 8, §2, para. 3 Act of 11 April on access to administrative documents; Council of State 29 May 2012, no. 219.523, Gozin.

144 Council of State 18 October 1999, no. 82.935, Duez.

145 Art. 22 Flemish Decree of 26 March 2004.

146 Art. 24, §1 Flemish Decree of 26 March 2004.

This period can be exceptionally extend that deadline with 15 days if the appeal body is of the opinion that the information requested will be difficult to collect in a timely fashion or of the verification of the application as regards to the grounds for exception is difficult to complete in time.

147 Flemish Appellate Body on the Openness of Government, Year Report 2015-2016, Brussel, 2016, available at: http://openbaarheid.vlaanderen.be/nlapps/data/docattachments/20170130145617589.pdf.

148 See VENY (2014), pp. 189. 
In no case the Council of State set itself in the place of the administrative authority; the Council of State has just a marginal judicial review in this respect. The administrative judge (Council of State) upon determining an illegality will only annul the contested decision without recognising any right for the requesting party. If the Council of State annuls a decision, it does not automatically imply that the access to documents is granted. It only implies that the administrative authority has to make a new decision, which could be the same as the annulled decision but with another motivation. In comparison with the appellate bodies, the Council of State doesn't take a new decision.

\section{Active transparency or ex officio transparency}

Article 32 of the Belgian Constitution only covers the passive component of transparency, namely that citizens has to request for documents and information. Yet transparency has two dimensions: an active one and a passive one. In the following section, we will discuss the relevant provisions regarding the active transparency of administrative authorities.

\subsection{Active transparency on the federal level}

The Federal Act contains a couple of provisions concerning active transparency. Evidently these are merely minimum requirements which do not prevent that each authority can undertake further initiatives to develop its communication policy. ${ }^{149}$

Four obligations are laid down in the Federal Act to ensure that the public is aware of the activities of the federal administrative authorities. First of all, a royal decree determines the organisation and the tasks of the federal public service and the federal administrative authorities which are obliged to establish a specialised body. The notion 'body' has to be interpreted broadly. It can be a specialised institution as well as a staff member that is (full time or part time) in charge of the information policy. This specialised body is entrusted with the conception and the realisation of the information policy. It is not necessary that these bodies provide the information themselves. They mainly have a guiding function. ${ }^{150}$

Secondly, each federal administrative authority has to publish a "where to go"-document with a description of its competences, its organisation and other information that is relevant for the public such as the opening hours of public services. This document must improve the accessibility of the administration for citizens. After all, an accessible administration can only be attained when it is clear to the public which authority and which staff member is competent for a specific matter. This document will be provided to anyone on request. ${ }^{151}$

Thirdly, all outgoing correspondence from a federal administrative authority must mention the contact person who can give more information regarding the case. The following information about the contact person must be given: name, function, address and phone number. ${ }^{152}$

Fourthly, there is an obligation to mention the appeal procedures that can be undertaken against an administrative decision with individual scope. This information has to be given in the same document in which the administrative decision is notified. The information about the appeal procedures includes the competent bodies for the appeal and their address, the period wherein the appeal has to be made and the applicable procedures. ${ }^{153}$

149 Explanatory Note Federal Act of 11 April 1994, 12.

150 Article 2, $1^{\circ}$ Federal Act of 11 April 1994; Explanatory Note Federal Act of 11 April 1994, 12.

151 Article 2, $2^{\circ}$ Federal Act of 11 April 1994; Explanatory Note Federal Act of 11 April 1994, 12-13.

152 Article $2,3^{\circ}$ Federal Act of 11 April 1994

153 Article 2, $4^{\circ}$ Federal Act of 11 April 1994; Explanatory Note Federal Act of 11 April 1994, 13

See for example Council of State 31 January 2012, no. 217.627, De Baere; Council of State 18 October 1999, no. 82.935, Duez. 
The information that must be provided according to the requirements of active transparency must be drafted in an understandable manner. This means that the information has to be adapted to the target group. In addition, the information must be objective and complete. ${ }^{154}$

The principle of active transparency doesn't imply that the government should provide on its own initiative to provide access to a file for a person without a request of the latter. ${ }^{155}$

8.2. Active transparency on the Flemish level

\subsubsection{Principle}

The Flemish Decree is more comprehensive than the Federal Act regarding to the active dimension of transparency. ${ }^{156}$ The instances mentioned in article $4, \S 1,2^{\circ}-8^{\circ}$ Flemish Decree 26 March 2004 are obliged to inform the public about its policy, regulations and service provision as well as about the rights of the people under this Decree. ${ }^{157}$ An aspect of the policy, the regulations or the provided services can either concern the public in general or a limited target group. The communication has to be directed to whom the information is relevant. Furthermore, the information has to be given systematic (this is consequently; not ad hoc), correct (this means that the instances must make every possible effort in order to disseminate only correct information and, if needed, rectify false information immediately), well-balanced (the instances must avoid one-sided information; they have to mention the outlines of each problem, without focusing more on some parts of it), in time (this is at the moment that the information is necessary or useful for the receiver) and in an understandable manner (this means that the instances must adapt the information in the light of the foreknowledge of the target group). ${ }^{158}$ However, the requirements within the framework of active transparency cannot lead to the dissemination of information which falls under the mandatory exceptions of passive transparency. ${ }^{159}$

\subsection{2. "Where to go" information and first-line information}

A database with "where to go" information and first-line information about the executive instances as mentioned in article 4, $\S 1$ of the Flemish Decree will be developed. The "where to go" information indicates where someone can find information about a specific subject or where someone can go for the handling of a problem or an administrative procedure. First-line information is basic information that is not related to a specific case. ${ }^{160}$ For example first-line information answers questions such as: "When are the school holidays this year?" or "How much is a fishing license?". For more complex information or information related to a specific case, the information seeker is referred to the competent executive instance. ${ }^{161}$

In order to grant access to the database in the most customer-friendly way as possible, access can be given electronic by phone or through a counter. Because of the proximity of local authorities (municipalities and provinces) it is recommended that especially these authorities make the "where to go" information and the first-line information accessible through their counters. In addition, access to this database will be open and free of charge for anyone. ${ }^{162}$ The obvious beneficiaries of the database are individual citizens, companies, institutions and associations, thus mostly private entities, who seek information. However the

154 Explanatory Note Federal Act of 11 April 1994, 12.

155 Council of State 8 March 2011, no. 211.844, XXX.

156 In fact, the Flemish Decree has the broadest policy concerning active access to documents within Belgium (see SCHRAM (2011), pp. 688).

157 Art. 28, $\$ 1$ Flemish Decree of 26 March 2004. Furthermore, the Flemish executive can name the instances as mentioned in article 4 , $\S 1,10^{\circ}$ which also have to respect this obligation.

158 Art. 28, §1 Flemish Decree of 26 March 2004; Explanatory Note Flemish Decree of 26 March 2004, 44

159 Art. 28, §2 Flemish Decree of 26 March 2004.

160 Art. 29, §1 Flemish Decree of 26 March 2004.

161 Explanatory Note Flemish Decree of 26 March 2004, 45.

162 Art. 29, §1, last paragraph Flemish Decree of Flemish Decree of 26 March 2004; Explanatory Note Flemish Decree of 26 March $2004,45$. 
database will also be useful for the executive instances themselves. Executive instances often have to refer applicants to each other, but it is not always clear for themselves which instance is competent for the matter requested. The database will make this easier for them. Overall it is expected that the rate of return and the time savings will outweigh the investments each executive instance has to make in order to realise the database. ${ }^{163}$

The Flemish government is responsible for the development and the direction of this database, with the assistance of the executive instances as mentioned in article $4, \S 1$ of the Flemish Decree. ${ }^{164}$ Given the complexity and the magnitude of this project, there is chosen for an approach in steps. In a first step the "where to go" information and the first-line information of the Flemish government will be made available in a product catalogue of the Flemish government. Later on, the information of other executive instances will be implemented. ${ }^{165}$

As long as the database is not complete, the provinces and the municipalities have to comply with their obligations under the Federal Act of 12 November 1997. ${ }^{166}$ This means that each province and each municipality must publish a document with a description of the competences and the organisation of every administrative authority that falls within the province or the municipality. ${ }^{167}$

\subsubsection{Communication officer}

A communication officer has to be appointed in each Flemish ministry, each internal autonomous public body with legal personality, each external autonomous public body, each province, each municipality and each public centre for social welfare. ${ }^{168}$ Besides the Flemish executive can appoint a communication officer in an internal autonomous public body without legal personality. ${ }^{169}$

Especially for public centres for social welfare a communication officer is considered to be of great importance. The reason for this is that public centres for social welfare usually work with target groups that are difficult to reach, such as underprivileged, elderly and members of an ethnic minority. While research has shown that these target groups have the most need for government information, these groups are the least reached by traditional communication methods. Therefore it is necessary that special efforts are made to reach these target groups. ${ }^{170}$

The communication officer is in charge of the preparation and realisation of the communication policy. He stimulates, coordinates and guides the communication of the concerned executive instance. Among others, his task consists of informing the public and the concerned target groups about the policy, specific decisions that affect them and the services provided by the concerned executive instance. In addition, the communication officer makes sure that all executive documents that are directed to citizens are drafted in a correct and understandable language. ${ }^{171}$ The requirement of an understandable language implies that the used vocabulary and the sentence structure are adapted to the target group. ${ }^{172}$

In order to fulfil their tasks, communication officers are entitled to access all useful documents. ${ }^{173}$

163 Explanatory Note Flemish Decree of 26 March 2004, 45

164 Art. 29, \$3 Flemish Decree of 26 March 2004.

165 Omz. VR 2006/26 concerning access to information. Available on: http://openbaarheid.vlaanderen.be/nlapps/docs/default.asp?id=26\#19 (26 July 2016). The product catalogue is available on the following website: http://productencatalogus.vlaanderen.be/.

166 Federal Act of 12 November 1997 concerning access to information in the provinces and the municipalities, BS 19 December 1997.

See also Explanatory Note Flemish Decree of 26 March 2004, 45

67 Art. $3,2^{\circ}$ Federal Act of 12 November 1997 concerning access to information in the provinces and the municipalities, BS 19 December 1997 ; art. 29, \$2 Flemish Decree of 26 March 2004 concerning access to administrative documents.

168 The obligation to appoint a communication officer does not imply that it has to be a full time function. Depending on the size of the municipality or public centre of social welfare and the dimension of the communication needs, the function can be either full time or part time. A full time function is recommended in municipalities of at least 20.000 citizens. In smaller municipalities there are possibilities for collaborations between municipalities. Another possibility is that one communication officer is appointed for both the municipality and the public centre for social welfare.

See: Explanatory Note Flemish Decree of 26 March 2004, 47-48.

169 Art. 31, §1-3 and §5 Flemish Decree of 26 March 2004.

170 Explanatory Note Flemish Decree of 26 March 2004, 47-48

171 Art. 32, §1-2 Flemish Decree of 26 March 2004.

172 Explanatory Note Flemish Decree of 26 March 2004, 48

173 Art. 32, §3 Flemish Decree of 26 March 2004. 
Although the communication officer has an extensive range of duties concerning communication, the Flemish legislator has emphasised that the communication officer is not solely responsible for the execution of the entire communication policy. On the contrary: communication is a task for the whole government. ${ }^{174}$

\subsubsection{Annual report}

The Flemish Decree imposes the Flemish executive to make an annual global report and an evaluation of the communication and the communication policy of the Flemish ministries, the internal autonomous public bodies with legal personality and the external autonomous public bodies. This annual report must be notified to the Flemish parliament. ${ }^{175}$

In order to increase the efficiency of communication and to obtain a maximum recognition of the Flemish government, the Flemish executive can impose further regulations on the instances mentioned in the paragraph above, concerning the generic aspects and the coordination of the communication policy. The generic aspects of communication are elements that are not specific for one instance but apply to the entire -or at least multiple sections of the Flemish government. Examples of generic aspects are the corporate design, the use of symbols and the manner in which the instances announce themselves abroad as official bodies of the Flemish government. ${ }^{176}$

\subsubsection{Requirements regarding the correspondence}

All outgoing correspondence from an instance within the Flemish community or the Flemish region -the instances mentioned in article $4, \S 1$ of the Decree- must mention the name, the capacity, the address and the phone number of the person who can give more information about the case. ${ }^{177}$ Each decision or administrative act with individual scope that aims to create legal effects for one or more governed or for another instance, must mention the possible appeal procedures that can be undertaken against the decision and the modalities of the appeal procedure. If these elements are not included in the notification, the period for appeal shall begin four months after the notification of the decision or the act with individual scope. ${ }^{178}$

\section{Overall assessment and some concluding remarks}

Access to information has in the last years' become a very powerful instrument for citizens. As we have explained, the regulation on access to documents in Belgium is very fragmented. Other than the Constitution which enshrines a general right, legislation also exists at the federal and regional level. However, as has become clear in this article, most of the time at the regional and federal level, similar rules apply. In this article we have explored the scope and exceptions at the federal level and gave some practical examples and issues. The contribution made clear that the duty to provide information has a very broad scope. It is not limited to the traditional authorities, but also refers to natural and legal persons which have characteristics of government (for example because of their special powers). It is also not limited to formal documents.

The exceptions applied in the studied regulations are not entirely the same, but they quite often protect the same interests so that there are no major differences in practice. Administrative and judicial protection ensures the strict application of the exceptions. Having said that: in practice often discussions arise on partial disclosure and/or on multiple requests. This is no coincidence. The requests can impose a very heavy burden on the administrative organisation of a government. The answer on the question of what is reasonable and where unreasonableness begins, is based on a delicate balance.

Explanatory Note Flemish Decree of 26 March 2004, 48.

Art. 33, §1 Flemish Decree of 26 March 2004.

76 Art. 33, §2 Flemish Decree of 26 March 2004; Explanatory Note Flemish Decree of 26 March 2004, 48.

177 Art. 34 Flemish Decree of 26 March 2004

178 Art. 35 Flemish Decree of 26 March 2004. 
Lastly, in Belgian law much attention is also paid to active transparency. The importance of this in practice, especially through the online provision of information through websites, continues to increase. This is a good thing for democracy and accountability.

In this way, can indeed be prevented that citizens if they wish certain information, should start time-consuming procedures. Furthermore, it's creating more transparency about the functioning of the administration and saves the administration focused searches. The documents are, after all, online. Two very recent initiatives that illustrate perfectly this trend:

The Flemish Government makes since September 2016 all the notes and notices relating to weekly government decisions available online (except for the documents in individual decisions (regarding a personal legal situation) and some confidential documents). By making these government documents public, the Flemish Government committed to greater openness and transparency and wanted to give more insight into the way policy is made.

A similar movement is noticeable at the federal level where, after legislative intervention, the advices on legislation and regulations, together with the texts which the advice relates too, of the Council of State are systematically (since January 1 , 2017) disclosed. ${ }^{179}$ That decision was very welcomed by academia.

179 Law of 16 august 2016, BS 14 september 2016. 
Annex I - Overview of access to documents in Belgium

\begin{tabular}{|c|c|c|}
\hline Section & Federal Act & Flemish Decree \\
\hline $\begin{array}{l}\text { Beneficiaries of access to } \\
\text { information }\end{array}$ & $\begin{array}{l}\text { Everyone (natural persons, NGO's, } \\
\text { non-profit organisations, public or } \\
\text { private companies,...) }\end{array}$ & $\begin{array}{l}\text { Everyone (natural persons, NGO's, } \\
\text { non-profit organisations, public or } \\
\text { private companies,...) }\end{array}$ \\
\hline Entities which are bound by the law & (Federal) Administrative authorities & (Flemish) Public authorities \\
\hline Request for access & Written (interpreted broadly) & Written (interpreted broadly) \\
\hline Detection of interest & Only for information of personal nature & Only for information of personal nature \\
\hline Response answer & No obligation & No obligation \\
\hline Timeframes to respond & 30 days, extendable to 45 days & 15 days, extendable to 30 days \\
\hline Exceptions & $\begin{array}{l}\text { Three categories: (i) relative } \\
\text { mandatory exceptions; (ii) absolute } \\
\text { mandatory exceptions and (iii) } \\
\text { discretionary exceptions. This last } \\
\text { category can only be invoked by } \\
\text { federal administrative authorities. }\end{array}$ & $\begin{array}{l}\text { Three categories: (i) relative } \\
\text { mandatory exceptions; (ii) absolute } \\
\text { mandatory exceptions and (iii) } \\
\text { discretionary exceptions. This last } \\
\text { category can only be invoked by } \\
\text { Flemish public authorities. }\end{array}$ \\
\hline Fees and costs & No costs, except for copy & No costs, except for copy \\
\hline Administrative remedies & $\begin{array}{l}\text { Federal Commission on Access to and } \\
\text { Reuse of Administrative Documents }\end{array}$ & $\begin{array}{l}\text { Flemish Appellate Body on the } \\
\text { Openness of Government. }\end{array}$ \\
\hline Judicial remedies & Council of State & Council of State \\
\hline
\end{tabular}


Annex II - Exceptions on access to documents in the Flemish Decree of 26 March 2004 concerning access to administrative documents

\begin{tabular}{|c|c|c|c|c|}
\hline \multirow[t]{2}{*}{ Exception } & \multirow{2}{*}{$\begin{array}{l}\text { Access to } \\
\text { administrative } \\
\text { documents }\end{array}$} & \multicolumn{3}{|c|}{ Access to environmental information } \\
\hline & & $\begin{array}{l}\text { General } \\
\text { information }\end{array}$ & $\begin{array}{l}\text { Information } \\
\text { regarding } \\
\text { emissions }\end{array}$ & $\begin{array}{l}\text { Information } \\
\text { regarding } \\
\text { Seveso's }\end{array}$ \\
\hline \multicolumn{5}{|c|}{ Optional exceptions } \\
\hline $\begin{array}{l}\text { The application remains manifestly unreasonable } \\
\text { or formulated in a too general manner }\end{array}$ & $\mathrm{X}$ & $\mathrm{X}$ & $\mathrm{X}$ & $\mathrm{X}$ \\
\hline Unfished or incomplete administrative documents & $\mathrm{X}$ & $\mathrm{X}$ & $\mathrm{X}$ & $\mathrm{X}$ \\
\hline \multicolumn{5}{|c|}{ Mandatory exceptions } \\
\hline Obligation to secrecy & Absolute & I & / & I \\
\hline Protection of individual privacy & Absolute & Relative & I & Relative \\
\hline $\begin{array}{l}\text { Confidentiality of deliberations of Flemish } \\
\text { authorities falling under the scope of the Decree }\end{array}$ & Absolute & Relative & / & l \\
\hline $\begin{array}{l}\text { Documents compiled exclusively for criminal or } \\
\text { administrative penalty proceedings }\end{array}$ & Absolute & Relative & Relative & Relative \\
\hline $\begin{array}{l}\text { Documents compiled exclusively for possible } \\
\text { implementation of disciplinary measures }\end{array}$ & Absolute & Relative & Relative & Relative \\
\hline $\begin{array}{l}\text { Information voluntarily provided by a third party } \\
\text { and designated as confidential }\end{array}$ & Absolute & Relative & / & Relative \\
\hline Economic, financial or commercial interest & Relative & / & l & / \\
\hline Confidential nature of international relations & Relative & Relative & Relative & Relative \\
\hline $\begin{array}{l}\text { Confidential nature of commercial and industrial } \\
\text { information }\end{array}$ & Relative & Relative & / & Relative \\
\hline $\begin{array}{l}\text { Dispensation of justice in civil or administrative } \\
\text { proceedings and possibility to obtain a fair trial }\end{array}$ & Relative & Relative & Relative & Relative \\
\hline $\begin{array}{l}\text { Confidentiality of actions of authority in so far as } \\
\text { this confidentiality is required for administrative } \\
\text { enforcement, performance of internal audit or } \\
\text { political decision-making process }\end{array}$ & Relative & Relative & / & l \\
\hline Public order and safety & Relative & Relative & Relative & Relative \\
\hline Protection of environment & I & Relative & I & I \\
\hline
\end{tabular}




\section{Bibliography}

ANDERSEN, R. (1999), “La mise en balance des intérêts en cause dans l'appréciation des motifs d'exception à la publicité de l'administration", $C D P K$, pp. 38-45.

BAMPS, C. (1996) “Openbaarheid van bestuur. De federale wet van 11 april 1994 toegelicht”, Rec. Arr. RvS, pp. 21-45.

BREMS, E. (1995), "De nieuwe grondrechten in de Belgische grondwet en hun verhouding tot het Internationale, inzonderheid het Europese Recht", TBP, pp. 619-636.

HEREMANS, T. (2011) Public Access to Documents: Jurisprudence between Principle and Practice (Between jurisprudence and recast), Gent: Academia Press.

LEWALLE, P., DONNAY, L. and ROUSOUX, G. (2008), "L'accès aux documents administratifs, un itinéraire sinueux”, in : D. RENDERS, ed., L'accès aux documents administratifs, Brussels: Bruylant, 2008, pp. 27-170.

MAST, A., DUJARDIN, J., VAN DAMME, M. and VANDE LANOTTE, J. (2014) Overzicht van het Belgisch administratief recht (Overview of Belgian administrative law), Mechelen: Kluwer.

ORNELIS, F. (1998) “Een nieuw openbaarheidsdecreet voor Vlaanderen”, in A.M. DRAYE, ed., Openbaarheid van bestuur. Stand van zaken, Leuven: Instituut voor Administratief Recht K.U.Leuven, pp. 11-36.

SCHRAM, F. (2008), Handboek Openbaarheid van bestuur, Brussels: Politeia.

SCHRAM, F. (2010), De federale openbaarheidswetgeving. Een introductie, Brussels: Politeia.

SCHRAM, F. (2011) "Access to Administrative Documents in Belgium: an Example of Transparency within the European Union”, REDC no. 3, pp. 663-699.

SCHRAM, F. (2013), De vlaamse openbaarheidswetgeving. Een introductie (An introduction to the Flemish legislation concerning access to information), Brussels: Politeia.

TIJS, R. (2011) De openbaarheid van bestuur. De werking van het Vlaams Openbaarheidsdecreet in de bestuurspraktijk, Gent: Larcier.

VANDE LANOTTE, J. and GOEDERTIER, G., Handboek Belgisch publiekrecht, Bruges: die Keure, 2010.

VAN NOTEN, W. (1981-1982), “De Raad van State en universitaire examens”, $R W$, pp. 491-493.

VENY, L. (2014) "The Complexity of Administrative Appeals in Belgium: Not Seeing the Woods for the Tress" in D.C. DRAGOS and B. NEAMTU, eds., Alternative Dispute Resolution in European Administrative Law, Berlin/Heidelberg: Springer, pp. 179-207.

VERSTEGEN, R. (2002) “Wanneer treden privaatrechtelijke (onderwijs)instellingen op als administratieve overheid”, $R W$, pp. 801-814. 